\title{
Studies on Prediabetes
}

\begin{abstract}
Atsushi NIKI
The 3rd Department of Internal Medicine, Nagoya University School of Medicine, Nagoya, Japan

(Director : Prof. Dr. Kozo Yamada)

Many reports have been presented on the statistics or diagnosis of prediabetes, but fewer studies have been attempted to elucidate the metabolic or hormonal disturbance in prediabetes. The present study was carried out in order to make some of these subjects clear.

The fluctuations of blood inorganic phosphorus and $47 \mathrm{P}$ after the administration of cortisone-glucose or insulin were less marked in prediabetics than that in normal subjects. The phosphorylation rates of vitamin $B_{1}$ and $B_{6}$ in the blood after the administration of these vitamins were lower in prediabetics than that in normal. Some prediabetics showed a decreased insulin sensitivity, and the plasma insulin level distributed in the wide range in prediabetics, as well as in normal or diabetics. The decreased insulin sensitivity of prediabetics who has the high plasma ins...n level was corrected by the use of pyridoxal phosphate, but that of prediabetics who have the low plasma insulin level was not corrected. Furthermore, prediabetics with a high plasma insulin level were found among the family having the diabetic with the high plasma insulin level, and vice versa.

These results suggest that prediabetics, as diabetics, are divided into the two types; one type, in which the insulin utilization is disturbed, and another type, in which insulin is lacking. In addition to that, the type of diabetes may be decided by the hereditary disposition.
\end{abstract}

\section{Studies on Plasma Free 17-Hydroxycorticosteroids in Pregnancy and Delivery}

\author{
Shuetsu SUZUKI \\ Department of Obstetrics and Gynecology, Faculty of Medicine, Keio Universty, Japan
}

(Director : Prof. Yoshio Sakakura)

In recent years, with the development of methods for the determination of circulating corticosteroids, major advances have been made on the investigation about the adrenal physiology during pregnancy and during neonatal life.

A relationship between maternal venous blood and cord blood concentrations of 17-Hydroxycorticosteroids (17-OHCS) at normal delivery has been demonstrated by many workers, but reports which compared the values at vaginal delivery with Caesarean section are fragmentary.

It was the purpose of this present study 1) to mesure the concentration of circulating free 17OHCS in normal Japanese women, and their variation during menstrual cycles ; 2) to observe the changes throughout the course of normal pregnancy, and in some cases, levels in toxemia of pregnancy ; 3) to determine the relationship existing between maternal and cord levels of plasma 17OHCS in cases of vaginal delivery and Caesarean section. 


\title{
糖尿病前症に関する研究
}

\author{
名古屋大学医学部山田内科 (指導山田弘三教授) \\ 仁 木
}

厚

(昭和37年 7 月 7 日受付)

緒言

現今糖尿病の誩断は耐糖能の異常に一定の基準を定め，異常の程度がその基準を超えた場合に下される。 しかるに一般に糖尿病の発症乃至は病態の発生は, 極めて徐々に潜行的に進展する。 それ故, 糖尿病者にお いては一定の基準に基づく臨床的な診断に先立つて, 糖代謝は勿論, 脂質, 蛋白質代謝その他内分泌の動態 等が発症後のそれに比して量的，てとによると質的な差異をもつて既存していたであろうことは容易に推定 出来る.

糖尿病においても早期に適切なる治療を加えることは，その進展を阻止する意味からも合併症の発生を防 止する意味からも必要なととである．かかる見地から糖尿病の極く初期又は発症前の病態を明確に把むとと は極めて重要な事である.

一方, 糖尿病の成因に関しては現今全く不明という他はない. 糖尿病が如何なる代謝異常を, ぞの様な順 序，程度に伴つて発症するかは，その成因を究明する上からも極めて興味ある事実である.

1954年 Fajans and Conn ${ }^{1)}$ は Cortisone-Glucose Tolerance Test による Prediabetes の診断法を提唱し た. 以来 Prediabetes に関する報告は数多いが，そのほとんどが診断法の検討と，それを用いての Prediabetes の発生率に関する統計的成績の報告に止まり，そこに見られる代謝異常を追求したものは未だ接する ことが出来ない.

私は Prediabetes にみられる代謝異常究明の一端として, 高エネルギー燐酸代謝及びインシュリンを中 心とする異常を追求し二三の知見を得た。

\section{実 験 対 照}

当内科外来及び入院加療中の糖尿病患者を問診し, 同一家系中 2 名以上の糖尿病患者を有する19家系を見 出し，その家系者中健常者とみなされる47名を選出した。これら47例につき下記の如くブドウ糖負荷試験 (Glucose-Tolerance Test一以下 GTT と略す) を行なつて, 糖尿病及び糖尿病の疑いを除く非糖尿病者41 例を実験対象とした。

\section{GTT の方法並びに基準}

被検者に早朝空腹時ブドウ糖を標準体重 $\mathrm{kg}$ 当 $1.5 \mathrm{~g}$ 経口投与し，投与前及び投与後 1 時間，2 時間の血糖 值を測定し，下記の基準に従つて糖尿病，糖尿病の疑い及び非糖尿病者に分けた。なお採血は全て耳架より 行ない，血糖值測定は Hagedorn-Jensen 法によつた。

1 時間血糖值 $180 \mathrm{mg} / \mathrm{dl}$ 以上

2 時間血糖值 $140 \mathrm{mg} / \mathrm{dl}$ 以上 $\}$ を糖尿病

$\left.\begin{array}{l}1 \text { 時間血糖值 } 179 \mathrm{mg} / \mathrm{dl} \text { 以下 } \\ 2 \text { 時間血糖值 } 130 \mathrm{mg} / \mathrm{d} 1 \text { 以下 }\end{array}\right\}$ を非糖尿病

上記以外を糖尿病の疑いとする.

この基準は Fajans and Conn'1)の基準が Somogyi 法による血糖值について定めてあるので，HagedornJensen 法による血糖值の相異を考慮に入れて，血糖值の基準を全て $20 \mathrm{mg} / \mathrm{dl}$ 高くしたものである. 


\section{実験方法並びに実験成績}

\section{I ) 糖尿病前症発症に関する統計的事項}

GTT で非糖尿病と判定された 41 例につき下記の要領でコーチゾン・ブドウ糖負荷試験 (Cortisone Glucose Tolerance Test一以下 CGTT と略す) を行なつた.

CGTT の方法並びに基準 ${ }^{1)}$

被検者に検査前 8 時間半及び 2 時間に酢酸コーチゾン $50 \mathrm{mg}$ （市販コートン使用）宛計 $100 \mathrm{mg}$ を経口投与 し，以下前記 GTT と同じ要領で検查を行ない，次の基準によつた.

1 時間血糖值 $180 \mathrm{mg} / \mathrm{dl}$ 以上

2 時間血糖值 $140 \mathrm{mg} / \mathrm{dl}$ 以上 $\}$ を糖尿病前症

1 時間血糖値 $179 \mathrm{mg} / \mathrm{d} 1$ 以下

2 時間血糖值 $130 \mathrm{mg} / \mathrm{d} 1$ 以下 $\}$ 在正常

上記以外を糖尿病前症の疑いとする.

なお GTT と CGTT は少なくとも 3 日の間隔を置いて行なつた，又概ね 10日以上の間隔は置かなかつ た. 又検査前の栄養状態は耐糖能に影響を与えるので ${ }^{2}$ ，検査前一定期間は一定の食事を掑らせる事が望ま しいが，今回はこの様な処置をとる事は不可能であつた。

CGTT の成績は第 1 表に見られる如く, 糖尿病前症者は約半数の 20 名 $(49 \%)$ で，糖 尿病前症の疑いの者は 12名 $(29 \%)$, 正常者 は9名 $(22 \%)$ であつた.

これを年令別にみると, 第 2 表に示す如く 高令者になる程糖尿病前症の発症率は高い傾 向があり，40才以上 6 名中では正常者が 1 名 あるのみで，他は全て糖尿病前症であつた。

第 1 表 CGTT の成續総括

\begin{tabular}{c|c|c|c}
\hline 症 例 数 & 糖尿病前症 & $\begin{array}{l}\text { 糖㽷病前症 } \\
\text { の疑い }\end{array}$ & 正 \\
\hline 41 & 20 & 12 & 9 \\
\hline & $49 \%$ & $29 \%$ & $22 \%$ \\
\hline & 4 & \multicolumn{3}{|c|}{$51 \%$} \\
\hline
\end{tabular}

第 2 表 年令よりみたる CGTT の成績

\begin{tabular}{|c|c|c|c|c|c|c|c|c|}
\hline & $0 \sim$ & $10 \sim$ & $20 \sim$ & $30 \sim$ & $40 \sim$ & $50 \sim$ & 60 才以上 & 計 \\
\hline 正 常 & 1 & 6 & 1 & 0 & 1 & 0 & 0 & 9 \\
\hline 前症疑 & 1 & 5 & 2 & 4 & 0 & 0 & 0 & 12 \\
\hline 前 症 & $\begin{array}{c}0 \\
(0 \%)\end{array}$ & $\begin{array}{c}4 \\
(27 \%) \\
\end{array}$ & $\begin{array}{c}5 \\
(63 \%) \\
\end{array}$ & $\begin{array}{c}6 \\
(60 \%) \\
\end{array}$ & $\begin{array}{c}2 \\
(66 \%)\end{array}$ & $\begin{array}{c}1 \\
(100 \%)\end{array}$ & $\begin{array}{c}2 \\
(100 \%)\end{array}$ & $\begin{array}{c}20 \\
(49 \%)\end{array}$ \\
\hline 計 & 2 & 15 & 8 & 10 & 3 & 1 & 2 & 41 \\
\hline
\end{tabular}

一方てれを出生序列より検討すると第 3 表 の如くになる，即ち，両親又はそのいずれか が糖疗病である10家系の子供 25 例についてみ るに, 明らかに出生序列の早い者程, 糖尿病 前症の発症率は高い。

次に，休型との関連を見るに，第 4 表に示 す如く, 肥満型 6 名中の糖尿病前症者は 2 名 (33\%) で，正常型28名における15名（54 $\%)$, 贏瘦型 7 名における 4 名 $(57 \%)$ に比 してむしろ低い.しかし逆に正常者は肥満型
第 3 表 出生序列よりみたる糖尿病前症発症 の傾问

\begin{tabular}{c|c|c|c|c|c}
\hline & 第 1子 & 第 2子 & 第 3子 & 第 4子 & 計 \\
\hline 正常 & 2 & 3 & 2 & 1 & 8 \\
\hline 前症疑 & 2 & 4 & 0 & 1 & 7 \\
\hline 前症 & $\begin{array}{c}6 \\
(60 \%)\end{array}$ & $\begin{array}{c}3 \\
(30 \%)\end{array}$ & $\begin{array}{c}1 \\
(33 \%)\end{array}$ & $\begin{array}{c}0 \\
(0 \%)\end{array}$ & 10 \\
\hline 計 & 10 & 10 & 3 & 2 & 25 \\
\hline
\end{tabular}


の者の中には見出されなかつた。

更に性別と糖尿病前症発症との関連は第 5 表に見る如く, 男性 15名中 8 名 $(53 \%)$, 女 性26例中12名 $(46 \%)$ で，男性においてやや 高率に見られた。なお妊娠中の耐糖能の減退 はよく知られているが゙が，今回の被検者中に は弤娠は一名もなかつた。

\section{II ）糖尿病前症における高エネルギー燐酸 代謝}

1) 血中無機燐並びに $\Delta 7 \mathrm{P}$

i）CGTT の血中無機燐並びに $47 \mathrm{P}$ に及ぼ す影響

前記の如く CGTT を行なうに際して, 空 腹時に肘静脈より採血，更にブドウ糖投与.30 分後に同㥞に採血して, 各々前值, 30分值の
第4表 体型よりみたる CGTT の成績

\begin{tabular}{c|c|c|c|c}
\hline & 肥満型 & 正常型 & 贏瘦型 & 計 \\
\hline 正常 & 0 & 6 & 3 & 9 \\
\hline 前症聟 & 4 & 8 & 0 & 12 \\
\hline 前 症 & $\begin{array}{c}2 \\
(33 \%)\end{array}$ & $\begin{array}{c}14 \\
(50 \%)\end{array}$ & $\begin{array}{c}4 \\
(57 \%)\end{array}$ & 20 \\
\hline 計 & 6 & 28 & 7 & 41 \\
\hline
\end{tabular}

第 5 表 性別よりみたる CGTT の成績

\begin{tabular}{l|r|r|r|c}
\hline & 前 症 & 前症疑 & 正 常 & 計 \\
\hline 男 & $8(53 \%)$ & $4(27 \%)$ & $3(20 \%)$ & 15 \\
女 & $12(46 \%)$ & $8(31 \%)$ & $6(23 \%)$ & 26 \\
\hline
\end{tabular}

測定に当てた．即ち，前值は 8 時間半及び 2 時間前にコーチゾン各 $50 \mathrm{mg}$ ，計 $100 \mathrm{mg}$ を投与された空腹時の 状態，30分值はそれにブドウ糖標準体重 $\mathrm{kg}$ 当 $1.5 \mathrm{~g}$ が負荷された状態の值を示す. 血中無機燐は FiskeSubbarow 法, 血中 $47 \mathrm{P}$ は Lohmann 法によつた.

実験成績を第 6 表に総括する，血中無機燐の前值では，正常者の平均 $3.89 \mathrm{mg} / \mathrm{dl}$ 亿対し，糖尿病前症，及

第 6 表 CGTT の血中無機燐及び $\Delta 7 \mathrm{P}$ に及ぼす影㗽

\begin{tabular}{|c|c|c|c|c|c|c|c|c|c|c|}
\hline & \multirow{2}{*}{$\begin{array}{l}\text { 症 } \\
\text { 例 }\end{array}$} & \multirow{2}{*}{$\begin{array}{l}\text { 年 } \\
\text { 令 }\end{array}$} & \multirow{2}{*}{ 性 } & \multirow{2}{*}{$\begin{array}{l}\text { 体 } \\
\text { 型 }\end{array}$} & \multicolumn{3}{|c|}{ 血中無機燐 $(\mathrm{mg} / \mathrm{dl})$} & \multicolumn{3}{|c|}{ 血中 $\Delta 7 \mathrm{P}(\mathrm{mg} / \mathrm{dl})$} \\
\hline & & & & & 前 值 & 後 值 & 減 少 & 前 值 & 後 值 & 増 加 \\
\hline \multirow[b]{4}{*}{ 糖 } & 1 & 51 & 우 & 正 & 4.06 & 3.98 & 0.08 & 4.16 & 4.85 & 0.69 \\
\hline & 2 & 41 & $\hat{\delta}$ & p & 3.82 & 3.71 & 0.11 & 3.79 & 3.87 & 0.08 \\
\hline & 3 & 33 & $\hat{o}$ & 正 & 4.25 & 4.15 & 0.10 & 3.80 & 3.90 & 0.10 \\
\hline & 4 & 16 & 우 & 正 & 3.56 & 3.40 & 0.16 & 2.89 & 3.19 & 0.30 \\
\hline 尿 & 5 & 21 & 우 & 正 & 3.50 & 3.32 & 0.18 & 3.50 & 3.86 & 0.36 \\
\hline \multirow{2}{*}{ 病 } & 6 & 39 & $\hat{o}$ & 正 & 3.75 & 3.75 & 0.00 & 3.20 & 3.20 & 0.00 \\
\hline & 7 & 48 & $\hat{\delta}$ & 肥 & 3.80 & 3.80 & 0.00 & 3.20 & 3.80 & 0.60 \\
\hline 前 & 8 & 32 & $\hat{\delta}$ & 正 & 3.78 & 3.65 & 0.13 & 3.32 & 3.60 & 0.28 \\
\hline \multirow[t]{3}{*}{ 症 } & 9 & 33 & $\hat{\delta}$ & 肥 & 4.12 & 3.90 & 0.22 & 3.41 & 3.62 & 0.21 \\
\hline & 10 & 27 & $\hat{\delta}$ & 正 & 3.03 & 2.72 & 0.31 & 3.01 & 3.19 & 0.18 \\
\hline & \multicolumn{2}{|c|}{ 平 } & \multicolumn{2}{|l|}{ 均 } & 3.77 & 3.64 & 0.13 & 3.43 & 3.71 & 0.28 \\
\hline \multirow{8}{*}{ 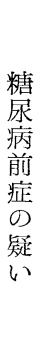 } & 1 & 15 & 우 & 正 & 3.72 & 3.25 & 0.47 & 3.85 & 4.19 & 0.34 \\
\hline & 2 & 36 & 우 & 肥 & 3.37 & 2.45 & 0.92 & 3.60 & 4.11 & 0.51 \\
\hline & 3 & 14 & 우 & 正 & 3.85 & 3.70 & 0.15 & 3.51 & 3.59 & 0.04 \\
\hline & 4 & 30 & $\hat{\delta}$ & 肥 & 3.68 & 3.46 & 0.22 & 3.90 & 3.95 & 0.05 \\
\hline & 5 & 32 & 우 & 正 & 3.08 & 2.31 & 0.77 & 3.40 & 3.82 & 0.42 \\
\hline & 6 & 30 & 우 & 正 & 3.30 & 3.10 & 0.20 & 2.60 & 3.02 & 0.42 \\
\hline & 7 & 15 & 우 & $や$ & 3.45 & 2.84 & 0.61 & 2.84 & 3.80 & 0.96 \\
\hline & & 平 & 均 & & 3.49 & 3.02 & 0.48 & 3.39 & 3.78 & 0.39 \\
\hline
\end{tabular}




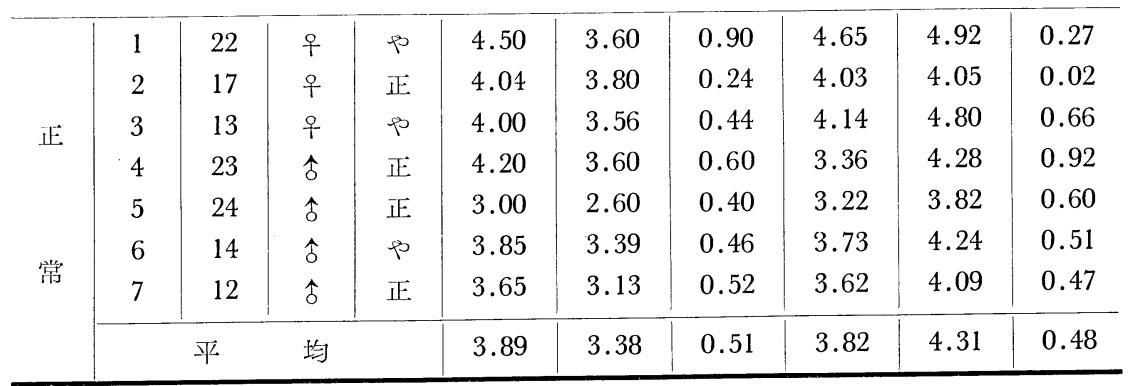

体型一正 : 正常型, 肥 : 肥満型, や : 贏溲型

びその疑いの者では各々平均 $3.77 \mathrm{mg} / \mathrm{dl}, 3.49 \mathrm{mg} / \mathrm{dl}$ とやや低值を示すが著明な差は認められない. 前値よ り 30 分值への減少量の平均值を比較すると, 正常者の $0.51 \mathrm{mg} / \mathrm{d} 1$ 亿対して, 糖㽷病前症では $0.31 \mathrm{mg} / \mathrm{dl}$ と低 值を示し，糖尿病前症の疑いは $0.48 \mathrm{mg} / \mathrm{dl} て ゙ ，$ 両者の中間の值を示す.

一方血中 $\Delta 7 \mathrm{P}$ の前值では, 正常者平均 $3.82 \mathrm{mg} / \mathrm{dl}$ に対し, 糖尿病前症及びその疑いは, 各々平均 3.43 $\mathrm{mg} / \mathrm{dl}, 3.39 \mathrm{mg} / \mathrm{dl}$ とやや低值を示す。更に前值より 30 分值への増加量の平均を見るに，正常者の0.48 $\mathrm{mg} / \mathrm{dl}$ に対して, 糖尿病前症では $0.28 \mathrm{mg} / \mathrm{dl}$ と低值を示し, 糖尿病前症の疑いは $0.39 \mathrm{mg} / \mathrm{dl}$ と両者の中間の 值を示した.

なお，第 6 表に見られる如く，正常者群においては30才以上の者が一名もなく，年令分布の相異が上記の 結果に影響を及ほしていることも考えられるので, 年令30才を境としてその前後における差を見た. 第 7 表 に見られる如くCGTT による血中無機燐の減少，血中 $47 \mathrm{P}$ の增加は29才以下の者に幾分高度に見られる

第 7 表 年令層よりみた CGTT の血中無機燐及び $47 \mathrm{P}$ に及ぼす影響

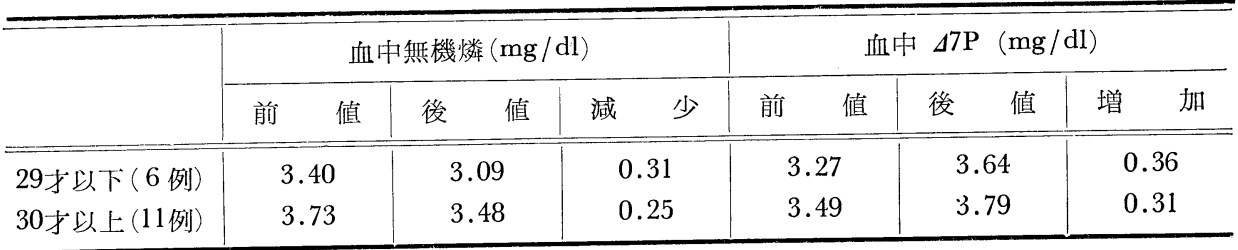

が，糖尿病前症者と正常者の間に見られる差に比べればその程度は少なく，年令による差を考慮に入れても なお糖尿病前症において高エネルギー燐酸代謝が障害される傾向は認められてよい.

ii）インシュリン投与の血中無機燐並びに $\Delta 7 \mathrm{P}$ に及ぼす影響

糖尿病前症 9 例, 糖尿病前症の疑い 4 例, 正常者 7 例について, インシュリン投与による血中無機燐並び に $47 \mathrm{P}$ の変動を見た.

早朝空腹時肘静脈より採血後，インシュリン（市販レギュラーインシュリン使用）体重 $\mathrm{kg}$ 当0.1単位を皮 下注射し，30分後再び肘静脈より採血して，各々前值，30分值の測定に当てた.

実験成績を第 8 表に総括する。血中無機燐の前值を見るに，正常者の平均 $3.88 \mathrm{mg} / \mathrm{d} \mathrm{d}$ 亿対して，糖尿病前 症並びにその疑いの平均值は各々 $3.76 \mathrm{mg} / \mathrm{dl}, 3.78 \mathrm{mg} / \mathrm{dl}$ とやや低值を示す. 前值より30分值への減少量の 平均值を比較すると，正常者の $0.43 \mathrm{mg} / \mathrm{dl}$ 亿比して，糖尿症前症並びにその疑いは，各々 $0.16 \mathrm{mg} / \mathrm{dl}, 0.19$ $\mathrm{mg} / \mathrm{dl}$ と著明な低值を示す.一方血中 $\Delta 7 \mathrm{P}$ の前値を見るに, 正常者の平均值 $3.77 \mathrm{mg} / \mathrm{dl}$ に対して，糖㽷病 前症並びにその疑いの平均值は, 各々 $3.45 \mathrm{mg} / \mathrm{dl}, 3.22 \mathrm{mg} / \mathrm{dl}$ とやや低值を示す. 且つ前值より 30 分值への 增加量は, 正常者の平均 $0.40 \mathrm{mg} / \mathrm{dl}$ 亿対して, 糖尿病前症並びに糖尿病前症の疑いの平均值は, 各々 0.29 $\mathrm{mg} / \mathrm{dl}, 0.18 \mathrm{mg} / \mathrm{dl}$ と明らかに低值を示している. 
第 8 表 インシュリン負荷の血中無機燐及び血中 $47 \mathrm{P}$ に及ぼす影響

\begin{tabular}{|c|c|c|c|c|c|c|c|c|c|}
\hline & \multirow{2}{*}{$\begin{array}{l}\text { 症 } \\
\text { 例 }\end{array}$} & \multirow{2}{*}{$\begin{array}{l}\text { 年 } \\
\text { 令 }\end{array}$} & \multirow{2}{*}{ 性 } & \multicolumn{3}{|c|}{ 血中無機燐 (mg/di) } & \multicolumn{3}{|c|}{ 血中 $\Delta 7 \mathrm{P}(\mathrm{mg} / \mathrm{dl})$} \\
\hline & & & & 前 值 & 後 值 & 減 少 & 前 值 & 後 值 & 増 加 \\
\hline \multirow{12}{*}{$\begin{array}{l}\text { 糖 } \\
\text { 尿 } \\
\text { 病 } \\
\text { 前 } \\
\text { 症 }\end{array}$} & 1 & 51 & 우 & 4.06 & 3.98 & 0.08 & 4.16 & 4.65 & 0.49 \\
\hline & 2 & 33 & $\hat{\delta}$ & 3.50 & 3.30 & 0.20 & 3.85 & 3.88 & 0.03 \\
\hline & 3 & 32 & $\hat{o}$ & 3.90 & 3.60 & 0.30 & 3.26 & 3.80 & 0.54 \\
\hline & 4 & 62 & 우 & 3.85 & 3.71 & 0.14 & 4.17 & 4.55 & 0.38 \\
\hline & 5 & 33 & 令 & 4.25 & 4.15 & 0.10 & 3.80 & 3.90 & 0.10 \\
\hline & 6 & 21 & 우 & 3.65 & 3.55 & 0.10 & 2.80 & 2.92 & 0.12 \\
\hline & 7 & 39 & $\hat{o}$ & 3.60 & 3.48 & 0.12 & 3.55 & 3.67 & 0.12 \\
\hline & 8 & 48 & $\hat{\rho}$ & 4.20 & 3.95 & 0.25 & 2.25 & 2.52 & 0.27 \\
\hline & 9 & 38 & 우 & 3.21 & 3.15 & 0.06 & 2.45 & 2.50 & 0.05 \\
\hline & 10 & 20 & 우 & 3.77 & 3.60 & 0.17 & 4.06 & 4.85 & 0.79 \\
\hline & 11 & 16 & 우 & 3.42 & 3.21 & 0.21 & 3.63 & 3.91 & 0.28 \\
\hline & \multicolumn{2}{|c|}{ 平 } & 均 & 3.76 & 3.61 & 0.16 & 3.45 & 3.74 & 0.29 \\
\hline \multirow{5}{*}{$\begin{array}{l}\text { 糖 } \\
\text { 湶 } \\
\text { 病 } \\
\text { 前 } \\
\text { 症 } \\
\text { 䈝 } \\
\text { 心 }\end{array}$} & 1 & 14 & 우 & 4.20 & 4.15 & 0.05 & 4.10 & 4.30 & 0.20 \\
\hline & 2 & 30 & $\hat{o}$ & 2.95 & 2.70 & 0.25 & 3.10 & 3.33 & 0.23 \\
\hline & 3 & 32 & 우 & 3.30 & 3.18 & 0.12 & 22.8 & 2.40 & 0.12 \\
\hline & 4 & 15 & 우 & 4.65 & 4.30 & 0.35 & 3.40 & 3.58 & 0.18 \\
\hline & \multicolumn{2}{|c|}{ 平 } & 均 & 3.78 & 3.58 & 0.19 & 3.22 & 3.40 & 0.18 \\
\hline \multirow{5}{*}{ 正 } & 1 & 43 & 우 & 3.54 & 2.92 & 0.62 & 3.20 & 3.66 & 0.46 \\
\hline & 2 & 17 & 우 & 4.00 & 3.45 & 0.55 & 4.00 & 4.50 & 0.50 \\
\hline & 3 & 14 & $\hat{o}$ & 4.30 & 3.96 & 0.34 & 3.65 & 3.95 & 0.30 \\
\hline & 4 & 12 & $\hat{\delta}$ & 4.50 & 4.20 & 0.30 & 3.30 & 3.55 & 0.25 \\
\hline & 5 & 22 & 우 & 3.43 & 3.01 & 0.42 & 3.82 & 4.24 & 0.42 \\
\hline \multirow{3}{*}{ 常 } & 6 & 13 & 우 & 3.62 & 3.24 & 0.38 & 4.27 & 4.63 & 0.36 \\
\hline & 7 & 11 & 우 & 3.76 & 3.40 & 0.36 & 4.18 & 4.66 & 0.48 \\
\hline & \multicolumn{2}{|c|}{ 平 } & 均 & 3.88 & 3.45 & 0.43 & 3.77 & 4.17 & 0.40 \\
\hline
\end{tabular}

\section{2) $B_{1}$ 負荷による血中，尿中 $B_{1}$ 量の変動と血中 $B_{1}$ 附燐率}

糖尿病前症者 6 名, 正常者 6 名につき, サイアミン塩酸塩負荷前後の血中総 $\mathrm{B}_{1}$, 結合 $\mathrm{B}_{1}$, 遊離 $\mathrm{B}_{1}$ 量, 及び負荷 2 時間後の尿中 $\mathrm{B}_{1}$ 排泄量を測定した。 なお入院加療中の糖尿病患者 3 名に対しても同様の試験を 行ない比較した。乙の被検患者の糖尿病の程度はいずれも中等症であり,インシュリン並びに経口糖尿病剤 により，血糖，尿糖検査の上から一応コントロールされたとみなされる状態を保つている者である。検查前 日より全ての楽剤投与を中止した。

早朝空腹時, 被検者に排尿せしぬ, 肘静脈より採血, 前値の測定に当てた。採血後, サイアミン塩酸塩 (市販メタボリン使用） $30 \mathrm{mg}$ を皮下注射し，30分後再び肘静脈より採血して 30 分値の測定に当て，又注射 2 時間後に採尿し，尿中 $\mathrm{B}_{1}$ 排泄量を測定した.

血中，尿中の $\mathrm{B}_{1}$ 測定はパームチットによるチオクローム螢光法 ${ }^{4}$ によつた。

実験成績を第 9 表に総括し, 前值及び 30 分值の附燐率の平均值を第 1 図に図示する.

第 9 表に見られる如く，糖尿病患者の血中結合 $B_{1}$ 量は， $B_{1}$ 負荷前においても負荷後 30 分においても共 に正常者より著明に低值を示し，又糖尿病前症者においては両者の中間の值を示す． 
第 9 表 $B_{1}$ 負荷による血中，尿中 $B_{1}$ 量の変動並びに $B_{1}$ 附燐率の比較

(サイアミン塩酸塩 $30 \mathrm{mg}$ 皮下注)

\begin{tabular}{|c|c|c|c|c|c|c|c|c|c|c|}
\hline & \multirow{2}{*}{$\begin{array}{r}r \% \\
\text { 症例 }\end{array}$} & \multicolumn{4}{|c|}{ 前 } & \multicolumn{4}{|c|}{30 分 值 } & \multirow{2}{*}{$\begin{array}{c}2 \text { 時間厡中 } \\
\mathbf{B}_{1} \text { 排沺 }\end{array}$} \\
\hline & & T.T & T. ph & F.T & $\begin{array}{c}\text { 附燐率 } \\
(\%)\end{array}$ & T.T & T. ph & $\mathrm{F} \cdot \mathrm{T}$ & $\begin{array}{c}\begin{array}{c}\text { 附燐率 } \\
(\%)\end{array} \\
\end{array}$ & \\
\hline \multirow{4}{*}{$\begin{array}{l}\text { 糖 } \\
\text { 病 }\end{array}$} & 1 & 6.0 & 3.6 & 2.4 & 60.0 & 21.6 & 9.6 & 12.0 & 44.4 & 4200.0 \\
\hline & 2 & 3.6 & 2.4 & 1.2 & 66.7 & 15.0 & 9.0 & 6.0 & 60.0 & 3360.0 \\
\hline & 3 & 4.8 & 2.4 & 2.4 & 50.0 & 18.0 & 4.0 & 14.0 & 22.2 & 7200.0 \\
\hline & 平 均 & 4.8 & 2.8 & 2.0 & 58.9 & 18.2 & 7.5 & 10.7 & 42.2 & 4922.0 \\
\hline \multirow{7}{*}{$\begin{array}{l}\text { 糖 } \\
\text { 病 } \\
\text { 前 } \\
\text { 症 }\end{array}$} & 1 & 7.2 & 6.6 & 0.6 & 91.7 & 18.0 & 12.0 & 6.0 & 66.7 & 1029.0 \\
\hline & 2 & 6.0 & 4.8 & 1.2 & 80.0 & 18.0 & 10.8 & 7.2 & 60.0 & 1920.0 \\
\hline & 3 & 7.2 & 6.0 & 1.2 & 83.3 & 19.2 & 14.4 & 4.8 & 75.0 & 1152.0 \\
\hline & 4 & 4.8 & 4.2 & 0.6 & 87.6 & 12.0 & 9.6 & 2.4 & 80.0 & 1663.2 \\
\hline & 5 & 4.8 & 3.2 & 1.2 & 66.7 & 19.2 & 13.8 & 5.4 & 71.9 & 5940.0 \\
\hline & 6 & 4.8 & 3.9 & 1.2 & 81.3 & 12.0 & 7.8 & 4.2 & 65.0 & 2428.8 \\
\hline & 平均 & 5.8 & 4.8 & 1.0 & 81.8 & 16.0 & 11.4 & 5.0 & 69.8 & 2355.6 \\
\hline \multirow{5}{*}{ 正 } & 1 & 8.4 & 7.2 & 1.2 & 85.7 & 22.8 & 16.8 & 6.0 & 73.7 & 2678.4 \\
\hline & 2 & 8.4 & 7.8 & 0.6 & 92.9 & 12.0 & 8.4 & 3.6 & 70.0 & 1800.0 \\
\hline & 3 & 6.0 & 4.8 & 1.2 & 80.0 & 18.0 & 13.2 & 4.8 & 73.3 & 720.0 \\
\hline & 4 & 7.2 & 5.4 & 1.8 & 75.0 & 18.0 & 13.2 & 4.8 & 73.3 & $2400.0^{*}$ \\
\hline & 5 & 7.2 & 6.0 & 1.2 & 83.4 & 15.6 & 12.0 & 3.6 & 76.9 & $1996.8^{*}$ \\
\hline \multirow[t]{2}{*}{ 常 } & 6 & 5.4 & 4.8 & 0.6 & 88.9 & 13.2 & 10.2 & 3.0 & 77.3 & $1140.0^{*}$ \\
\hline & 平 均 & 7.1 & 6.1 & 1.1 & 84.3 & 16.6 & 12.3 & 4.3 & 74.2 & $1732.8^{*}$ \\
\hline
\end{tabular}

T.T : 総 $\mathrm{B}_{1} \quad \mathrm{~T} . \mathrm{ph}:$ 結合 $\mathrm{B}_{1} \quad \mathrm{~F} . \mathrm{T}:$ 遊離 $\mathrm{B}_{1}$

* 正常者症例 $4,5,6$ の尿中 $\mathrm{B}_{1}$ 排泄量は 6 時間值.

故に平均值は症例 $1,2,3$, についてのみ計算

一方第 9 表及び第 1 図に示す如く, 前值における血中 $\mathrm{B}_{1}$ 附燐率は, 正常者の $84.3 \%$ 亿比して糖尿病者は $58.9 \%$ と明らかと低值を示す. 糖尿病前症においては $81.8 \%$ と僅か減少の傾向を示す.

$\mathrm{B}_{1}$ 負荷 30 分後の血中 $\mathrm{B}_{1}$ 附燐率は，第 1 図に見られる如く，前值におけると全く同様の傾向を示す。即 ち正常者の $74.2 \%$ 亿対し, 糖尿病者では $42.2 \%$ と著明な低值を示し, 糖尿病前症では $69.8 \%$ とやや低下の傾 向を示す．且 $\mathrm{B}_{1}$ 負荷により, 糖尿病前症と正常との差は幾分大きくなる.

\section{3) $B_{6}$ 負荷による血中 $B_{6}$ 附燐の比較}

糖尿病前症者 12 名, 正常者 8 名について, ピリドキシンを投与し, 投与前後における血中ピりドキサール 燐酸量の変動を比較した。なお入院加療中の糖尿病患者 4 名にも同様の試験を行ない比較に供した。

早朝空腹時に被検者の肘静脈より採血，次いでピリドキシン（市販へキゼルミン使用） $40 \mathrm{mg}$ を皮下注射 し，30分後に再び採血し，各血中のピリドキサール燐酸量を測定した。ピリドキサール燐酸の測定は大腸菌 のトリプトファナーゼを用いる市原氏法占によつた。

実験成績は第 10 表の如くで，早朝空腹時の血中ピリドキサール燐酸量の平均値は，糖尿病前症，正常者共 に2.5 $/ \mathrm{dl}$ で差はない. 糖尿病患者では $1.9 \gamma / \mathrm{dl}$ と低值を示す. 更にピリドキシン $40 \mathrm{mg}$ 負荷後 30 分の血中ピ リドキサール燐酸量を，早朝空腹時のそれと比較すると，一例を除く他の全例に增加を見たが，その増加量 の平均は, 正常者における $1.8 \gamma / \mathrm{d} l$ 亿対して, 糖尿病前症者は $1.1 \gamma / \mathrm{dl}$ と可成りの低值を示し, 糖尿病者にお 
第 1 図 糖尿病，糖尿病前症，正常者に打ける血 中 $\mathrm{B}_{1}$ 附燐率の比較

（前值及びサイアミン塩酸塩 $30 \mathrm{mg}$ 皮注後 30分值）

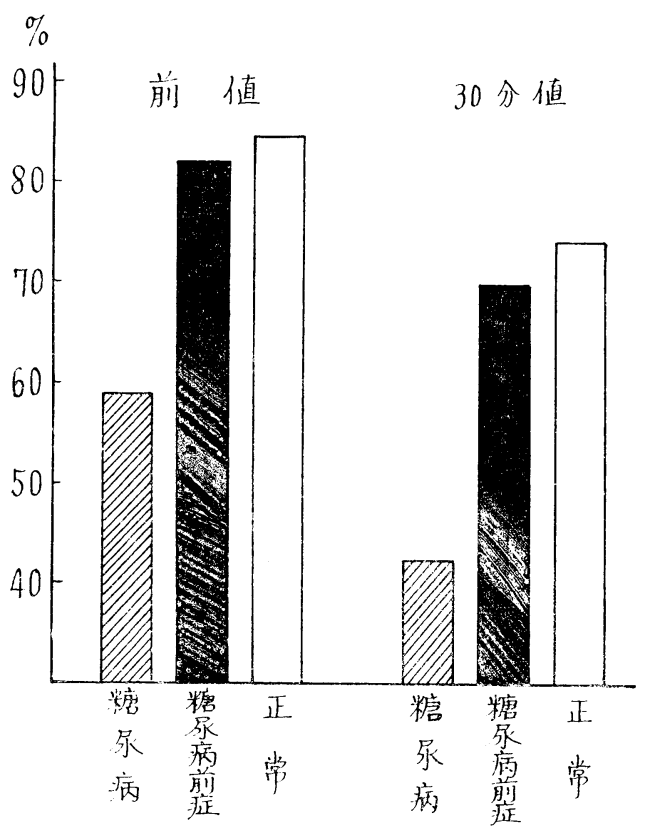

いては 0.9r/dl と更に低い. てれら增加量の早朝空 腹時における血中ピリドキサール燐酸量に対する割 合を百分率により現わすと，正常者における $85.7 \%$ に比して, 糖尿病前症並びに糖尿病者においては, 各々 $54.5 \%, 66.4 \%$ と低值を示す.

\section{III）糖尿病前症におけるインシュリン感性}

糖尿病患者においては,インシュリン感性が正常 の者と低下している者とがあることはよく知られた 事実である ${ }^{6)}$. 糖尿病前症においても，すでにイン シュリン感性の低下をみる者があるか否かを知るた

め，糖尿病前症及びその疑いの者 18 名と，正常者 5 名を対象としてインシュリン感性試験を行なつた.

早朝空腹時，被検者に体重 $\mathrm{kg}$ 当 0.1 単位のインシュリンを皮下注射し，注射前及び注射後 30 分，45分，60 分, 90分，120分の血糖值を測定し感性曲線を求めた。 又

注射前血糖値 $(\mathrm{mg} / \mathrm{dl})$ - 最低血糖值 $(\mathrm{mg} / \mathrm{dl})$

最低血糖值に到る時間(分)

の式よりインシュリン感性指数を求めた.

インシュリン感性曲線は第 2 図に見られる様に, 糖尿病前症及びその疑いの群は各血糖値に相当のばらつ きを示すが，正常群に比して明らかに感性の低下の傾向を示す．個々の症例について感性指数を求めると第 3 図に示す如く，糖尿病前症及びその疑いの群は正常值を示す者もあるが，著明な低下を示す者も多く，そ の平均值は0.47で正常群の平均值 0.91 に比して明らかに低值をとる.

$$
\text { 第38巻 第10号 }
$$




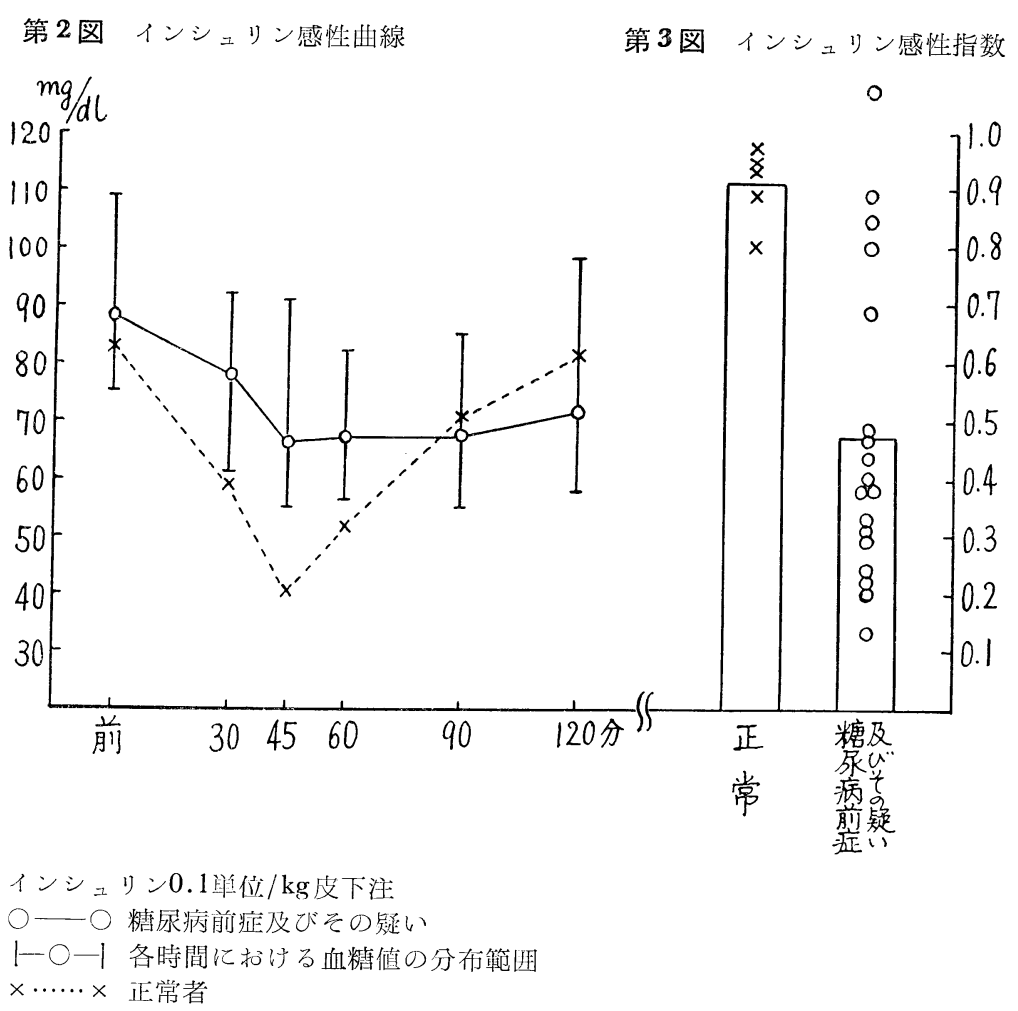

又糖尿病者においては，通常若年性のものはイン シュリン感性が高く，向老性のものはそれが低いて とか知られている ${ }^{6}$ ので，上述の成績を年命との関 連において見たが，第 4 図に示す如く両者の間に相 関は胃られなかつた。

なお血中インシュリン量との関連は後述する。

IV) 糖尿病前症における血中インシュリン量

1) 血中インシュリン量

糖尿病患者 13 名及びその家系者 31 名(糖尿病前症 者13名, 糖尿病前症の疑いの者11名, 正常者 7 名) における早朝空腹洔の血中インシュリン量を測定し た. 同時に対照として非糖尿病家系の正常者の血中 インシュリン量を測定した.

血中インシュリン量の測定は当教室山田・柴田の

第 4 図精尿病前症者に扎ける年令とインシ コリン感性指数との関連

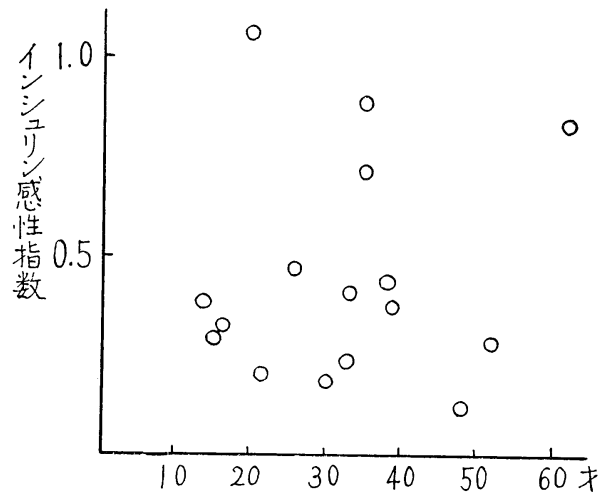

方法てとよる。

第 5 図に見られる如く，糖尿病家系者の血中インシュリン量值は，糖㽷前症，前症の疑い，及び正常者の いずれにおいても，糖尿病者又は刘照正常者と同様極めて広範囲の分布を示し，著明な差異は認められな い. 但し糖㽷病者にみられる如く測定不能に近い程の低值を示すものはなかつた。

糖尿病家系者の血中インシュリン量と年令との関連は第 6 図に示す如くで，40才以上の糖尿病前症者では 低值を示し，20才以下の糖尿病前症者はいずれも高值を示した。

$$
\text { 第38滛 第 } 10 \text { 号 }
$$


更に，体型との関連は第7 図に見られる如く, 䇔 瘦型の糖尿病前症者はいずれも低い血中インシュリ ン量を示す. 肥满型, 正常型の者においては特別の 傾向を認めなかつた。

2) 血中インシュリン量と高エネルギー燐酸代謝 との関連

第 5 図に示された血中インシュリン量と, 第 6 表 に示された CGTT による血中無機燐及び $47 \mathrm{P}$ 変 動並びに第 8 表に示されたインシュリン負荷による 血中無機燐及び $\Delta 7 \mathrm{P}$ 変動値との関連を同一症例に ついて見ると，各々第 8 図，第 9 図，第 10 図，第 11 図任見られる如くである. 即ち, 第11図の血中イン シュリン量と CGTT による血中 $47 \mathrm{P} の$ 変動との間 に負の相関の傾向をみるほかは，一定の関連を認め なかつた。

3) 血中インシュリン量とインシュリン感性との 関連

糖尿病前症者においては, インシュリン感性の低 下を示す者のあるととは既に述べた。

又教室小出の報告8) によれば，糖尿病患者を血中

第 6 図 糖尿病家系者の血中 インシュリン量と年令との関連

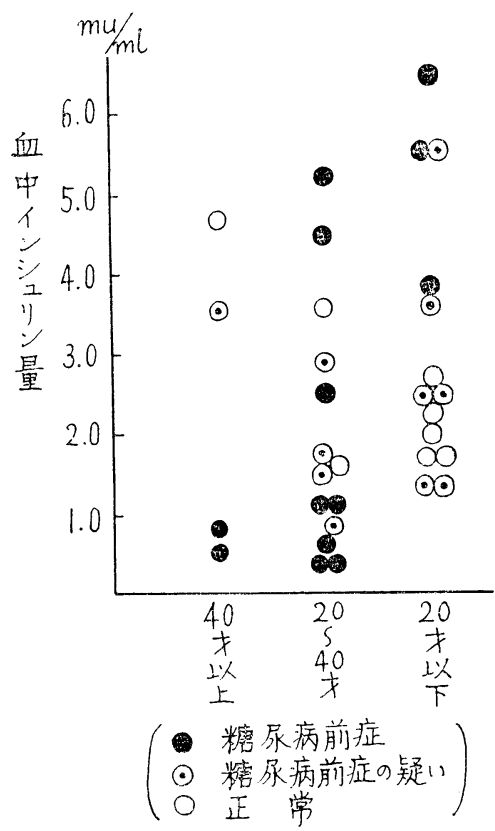

第 5 図 糖尿病家系者の血中インシュリン量

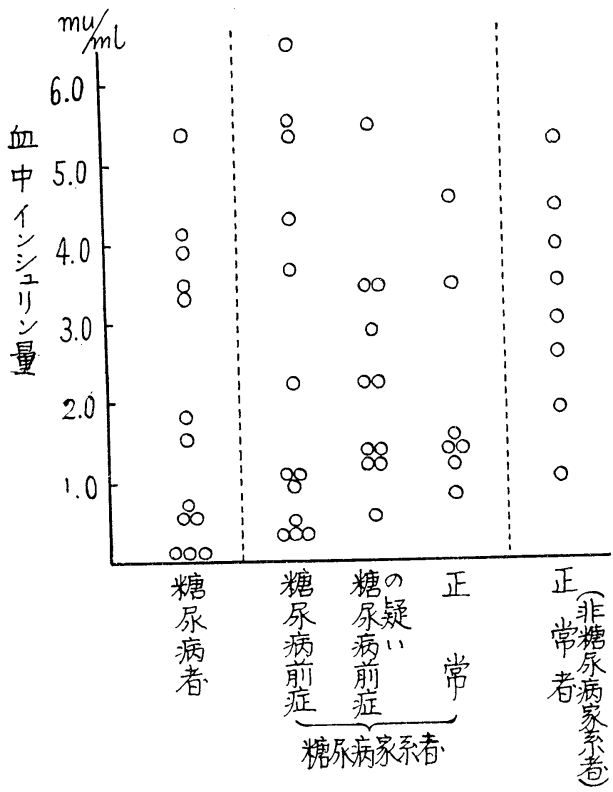

第 7 図栫尿病家系者の血中 インシュリン量と体型との関連

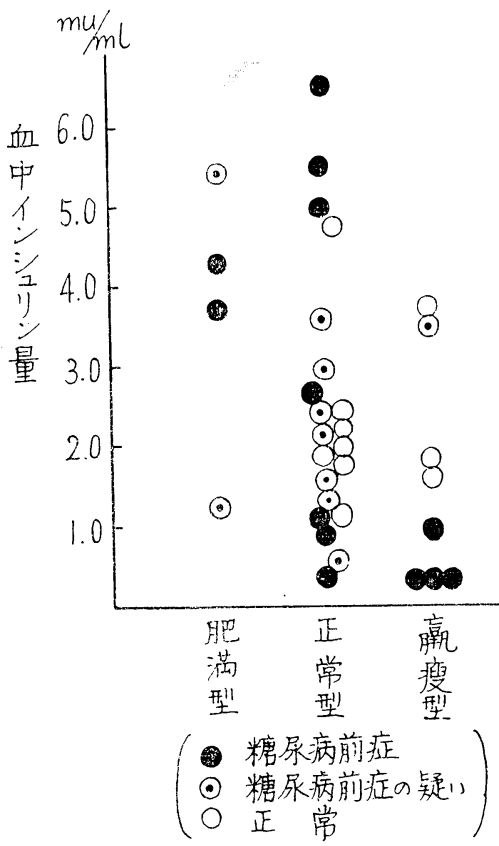


第8図 血中インシュリン量とCGTTによ る血中鮥機燐の変動との関連

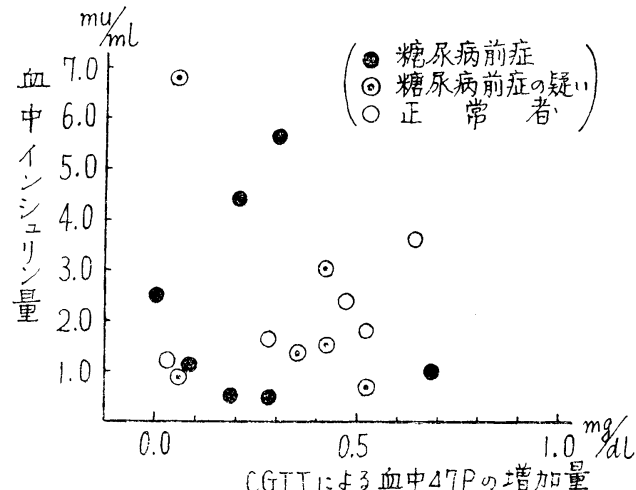

第10図 血中インシュリン量とインシュリン負荇 による血中無機燐の変動との関逈

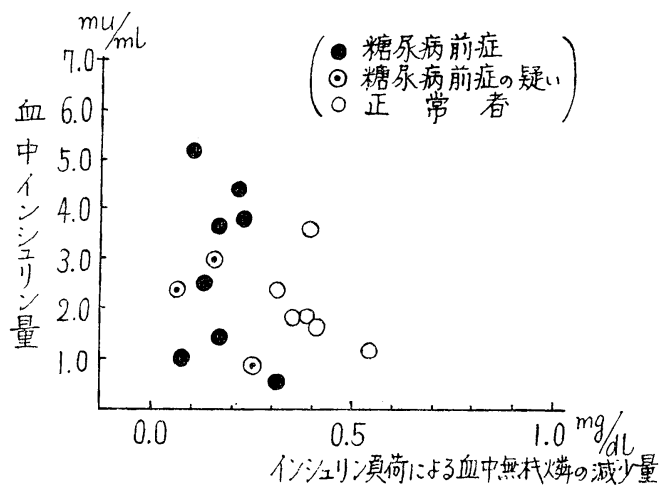

第9図 血中インシュリン量と CGTT によ る血中 $\Delta 7 \mathrm{P}$ の変動との関連

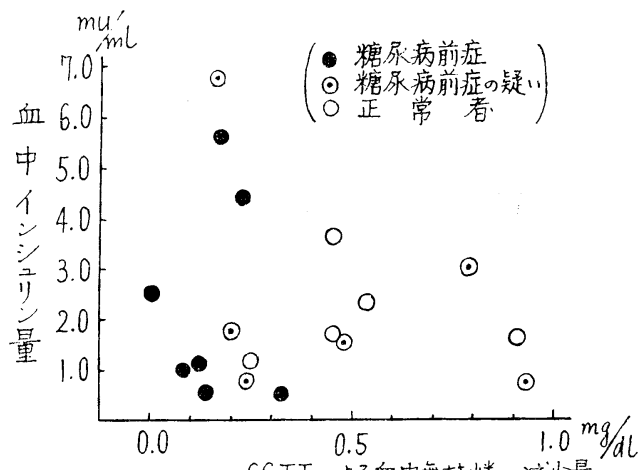
CGTTによる血中無杖燐の減少量

第11図 血中インシュリン量とインシュリン負荷 による血申 $47 \mathrm{P}$ の変動との関連

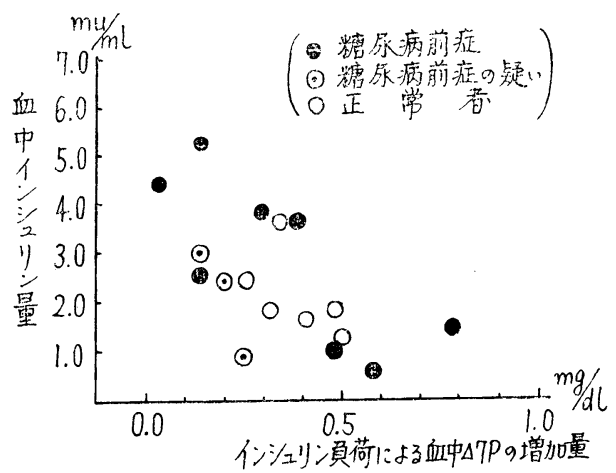

インシュリン量の面より検討する時，血中インシュリン墨の低いいわゆるインシュリン久乏型と，血中イン シュリン量は正常である。いわゆるインシュリン利用障害型があり，後者に Pyridoxal phosphate (以下 PAL-P と略す）を投与する時，インシュリン利用障害に基づく諸代謝異常の是正が見られる者が多い，イ ンシュリン感性に関しては，インシュリン単独投与において感性の低下，感性指数の低值を示す者が, PAL$\mathrm{P}$ を同時に投与すると，てれらの增加を見るという。

糖尿病前症及びその疑いの者14名についてかかる見地から検討を加えた。

即ち前述のインシュリン感性試験にてインシュリン感性指数を求め, 数日後, 同一症例に全く同様の条件 でインシュリン感性試験を行なう時，インシュリン皮下注射と同時に，PAL-P (市販ピドキサール使用) $10 \mathrm{mg}$ を静脈内注射して感性指数を求め両者を比較した．血中インシュリン量とを総括して表示すると第11 㤗の如くである。

これらの成績より，先ず血中インシュリン量とインシュリン感性指数との関連を見ると第12図の如くであ り，インシュリン単独投与の場命には何らの相関を楒めないが，インシュリンと PAL-P 同時投与の場合に おいては正の相関を示す傾向が涩められる。

そこで PAL-P を併用するととによるインシュリン感性指数の変化と血中インシュリン量との関連を見る と第13図の如くである。即ち第11表において PAL-P による感性指数の变化が+0.4以上のものを感性増加 第38巻 第 10 号 
第11表 糖尿病家系者のインシュリン感性指 数に及ぼす PAL-P の影響 インシュリン0.1単位 $/ \mathrm{kg}$ 皮下注, PAL-P $10 \mathrm{mg}$ 静注

\begin{tabular}{|c|c|c|c|c|c|}
\hline \multirow{2}{*}{ 症例 } & \multicolumn{3}{|c|}{ インシュリン感性指数 } & \multirow{2}{*}{$\begin{array}{l}\text { 感性の } \\
\text { 変化 }\end{array}$} & \multirow{2}{*}{$\begin{array}{l}\text { 血中「イ」 } \\
\text { 量 } \\
(\mathrm{mu} / \mathrm{ml})\end{array}$} \\
\hline & $\begin{array}{l}\text { インシ } \\
\text { リン单独 }\end{array}$ & $\begin{array}{c}\text { PAL-P } \\
\text { 併用 }\end{array}$ & \begin{tabular}{|} 
PAL-Pに \\
よる変化
\end{tabular} & & \\
\hline 1 & 0.30 & 0.96 & +0.66 & 増加 & 2.5 \\
\hline 2 & 1.14 & 1.82 & +0.68 & " & 3.0 \\
\hline 3 & 0.74 & 1.31 & +0.57 & " & 4.8 \\
\hline 4 & 0.40 & 0.94 & +0.54 & " & 3.8 \\
\hline 5 & 0.41 & 0.93 & +0.52 & " & 4.4 \\
\hline 6 & 0.37 & 1.07 & +0.70 & " & 3.0 \\
\hline 7 & 0.31 & 0.72 & +0.41 & " & 2.0 \\
\hline 8 & 0.30 & 0.47 & +0.17 & 不変 & 3.6 \\
\hline 9 & 0.40 & 0.52 & +0.12 & " & 0.5 \\
\hline 10 & 0.22 & 0.44 & +0.22 & " & 1.0 \\
\hline 11 & 1.13 & 1.03 & -0.10 & " & 1.4 \\
\hline 12 & 0.36 & 0.40 & +0.04 & " & 2.4 \\
\hline 13 & 0.22 & 0.17 & -0.05 & " & \\
\hline 14 & 0.56 & 0.59 & +0.03 & " & 0.5 \\
\hline
\end{tabular}

第12表 血中インシュリン量の傾向よりみた 糖尿病家系者と CGTT の成績

\begin{tabular}{|c|c|c|c|c|}
\hline \multirow[b]{2}{*}{ 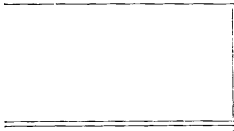 } & \multirow{2}{*}{ 人員 } & \multicolumn{3}{|c|}{ GGTT の成績 } \\
\hline & & $\begin{array}{l}\text { 糖尿病前 } \\
\text { 症 } \\
\end{array}$ & 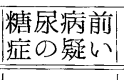 & 正 常 \\
\hline $\begin{array}{l}\text { 血中「イ」量の多 } \\
\text { 心糖尿病者の家系 } \\
\text { (7家系) }\end{array}$ & 17人 & $\begin{array}{c}6 \text { 人 } \\
35.3 \%\end{array}$ & $\begin{array}{c}6 \\
35.3\end{array}$ & $\begin{array}{c}5 \\
29.4\end{array}$ \\
\hline $\begin{array}{l}\text { 血中「イ」量の少 } \\
\text { い粕原病者の家系 } \\
\text { (6家系) }\end{array}$ & 16人 & $\begin{array}{c}7 \text { 人 } \\
43.8 \%\end{array}$ & $\begin{array}{c}5 \\
31.2\end{array}$ & $\begin{array}{c}4 \\
25.0\end{array}$ \\
\hline
\end{tabular}

群, 土0.4以内のものを感性不変群とし, 両群におけ る血中インシュリン量を比較すると，第13図の如くで あり，前者においては後者に比して明らかに血中イン シュリン量の高い値を示す傾向を認める.

\section{4) 糖尿病患者とその家系者に見られる血中インシ ュリン量の傾向}

糖尿病患者を血中インシュリン量の多い群と少ない 群に分け，その両群の患者の家系者における血中イン シュリン量を検討した.

\section{被検対象を第12表に総括する.}

糖尿病患者を血中インシュリン量が $1.0 \mathrm{mu} / \mathrm{ml}$ 以上の者と以下の者に分け，前者を血中インシュリン量の 多い患者, 後者を少ない患者とすると夫々 7 名及び 6 名の患者が該当した．乙れら各患者の家系者それぞれ 第38巻 第10号
第12図 血中インシュリン量とインシュリン 感性指数との関連

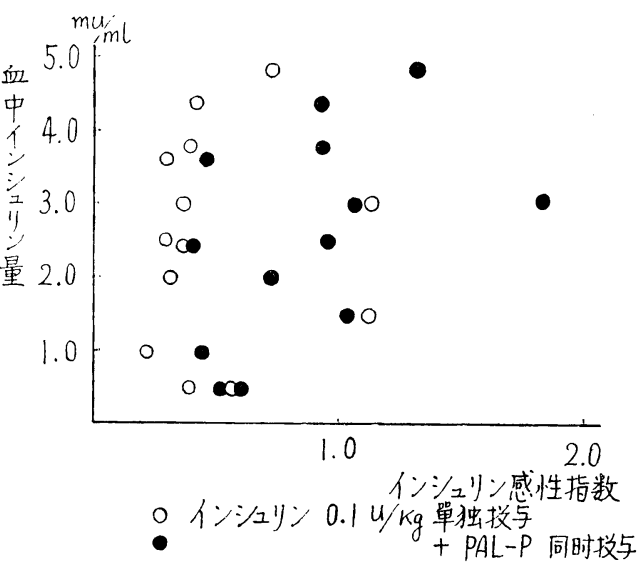

第13図 糖㽷病系者の $\mathrm{PAL}-\mathrm{PO}_{4}$ に よるインシュリン感性の変 化と血中インシュリン量と の関連

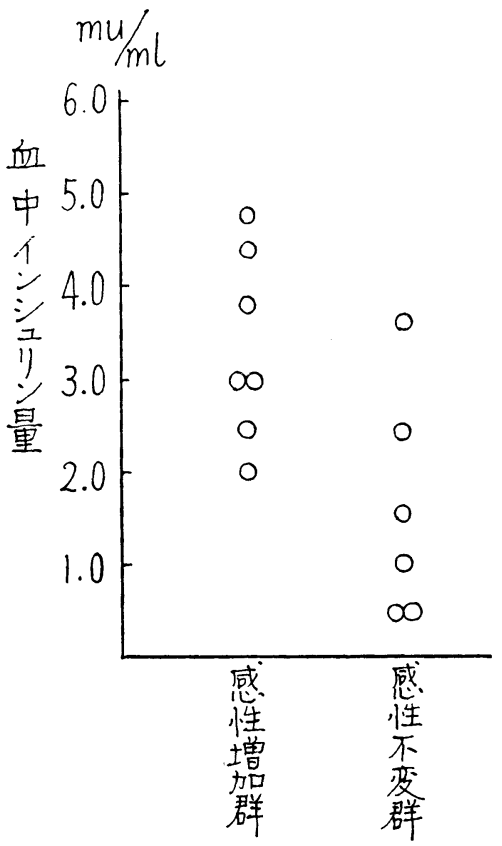


第14図 血中インシュリン量よりみた糖尿病患者とその家系との関連

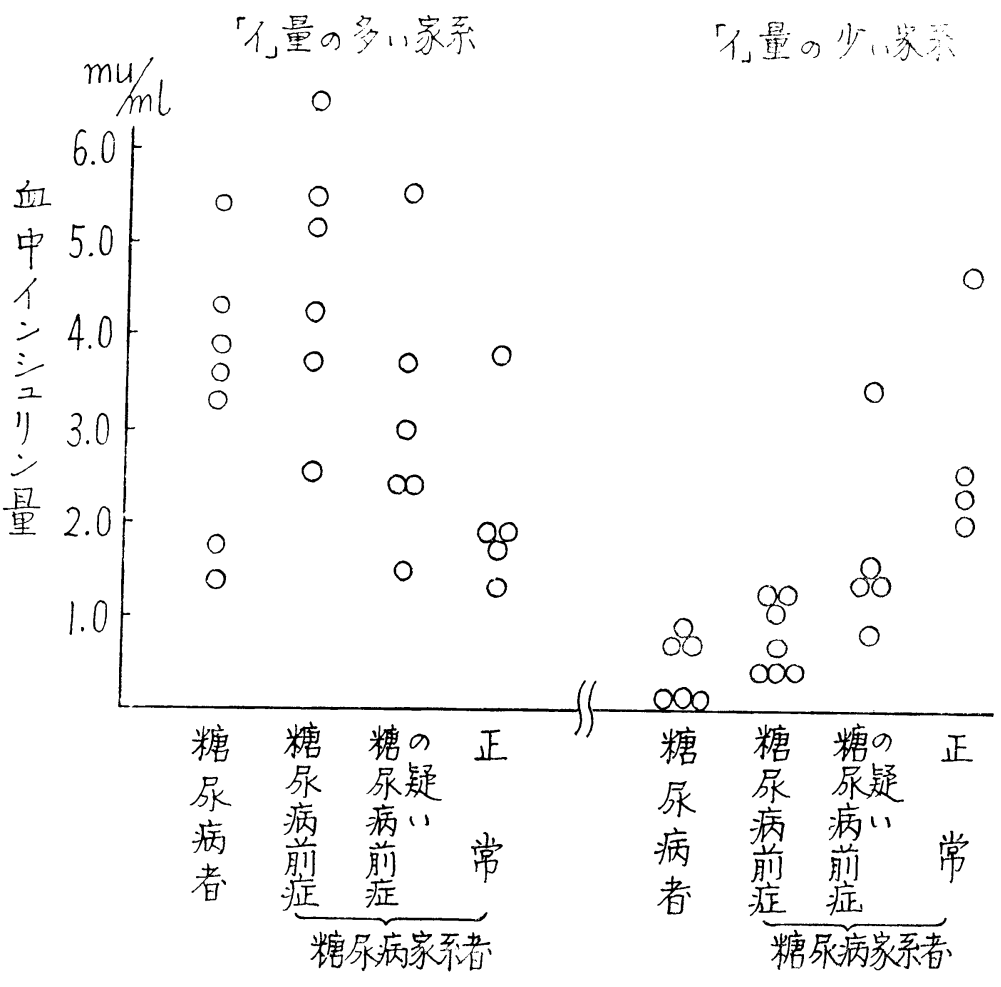

17名，16名について GGTT の結果をみると，第12表の如く，糖尿病前症，及びその疑い，正常者の割合は ほぼ同じである。

これら 2 群の患者及びその家系者の血中インシュリン量を比較すれば, 第14図に示す如くで，血中インシ ニリン量の多い糖尿病患者の家系の非正常者の向中インシュリン量は，正常又はそれ以上の高値を示す。一 方インシュリン量の少ない糖尿病患者の家系の非正常者のそれはやはり低值を示す, 又両家系中の正常者に ついては，ての傾向は見られなかつた。

\section{総括並びに考按}

本報告にいう糖尿病前症とは Prediabetes の意であり, 将来糖尿病に発展する前段階の状態を意味する. 糖尿病前症の診断法として本報告に用いた CGTT は1954年 Fajans and Conn そより提陧された $。$ 。これよ り先に ACTH が正常人に一過性の糖尿病状態を起すととが見られ99，続いて Cortisone も同様な作用を有 する事が報告された ${ }^{10)}$. CGTT は，かかる Cortisone の diabetogenic effect を耐糖能試験に組合わせる ことにより，耐糖能の障害をより鋭敏に見出そうとするものである.

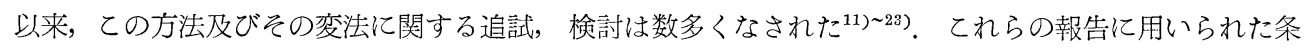
件は種々の点で多少の差異はあるが，GGTT の糖尿病前症に対する䛦断的価値に関しても又必ずしも一致 した意見を見ていない。

糖尿病の素因が遺伝性であるととはよく知られており, 前記諸報告も CGTT の家系者中の健常者と, 非 家系者中の健常者に対する態度から, その診断的価值を論ずるものが多く, 且つ家系者にその陽性率が大で あるとするものが多いが(111)13)17)21)，有意の差を認めないものもある ${ }^{1829}$. 他方，巨大巟出産又は死産をな 
した婦人が糖原病前症である確率は高く，殊にその死産児の膵ラ氏島に肥大が兄られる事実は興味を持たれ

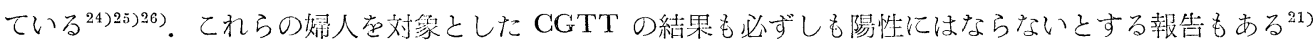
27).

いうまでもなくCGTT の目的は，将来の糖尿病への発展の予意にあるが，てれを嬉付けるべく被検者の 糖尿病への発展の有無を経時的に追求した報告は少なく ${ }^{28)}$ ，本法の提唱者の Conn 等も言う如く ${ }^{28) 29) ， 乙 ~}$ の方法が妥当であるか否かの結論は，なお将来の統計の集皘を待たなければならない。

以上の如く，糖尿病前症の讋断には未だ決定的な方法が磼立されていないが，本報告では現今比較的多く の承認を得ていると思われる CGTT をもつて診断珰てた.

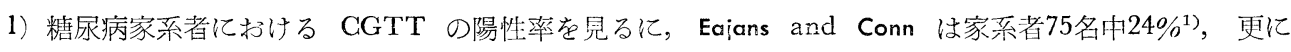
215名の家系者中非糖尿病である76\%の者のうちの $25 \%{ }^{11)}$ 亿陽性者を見たとしている．又 West ${ }^{13)} 20 \% ，$ 後藤等 ${ }^{17}$ は 17 名中 6 名 $(35 \%)$ の陽性者を見ている. Sanders 等 ${ }^{21)}$ は家系者42名中25名 (58\%) に陽性者が あるとし，本報告における41名中陽性者 20 名 $(49 \%)$ とほぼ近い值を報告している。乙れらの報皆は対象の 選び方, 条件, 判定の基準等において多少の差異はあるが，いずれにしても Sarders 等の報告, 及び本報 告における陽性者発見率は，他のそれに比して極めて高い。

又年令と CGTT との関連を見ると，高命者程 CGTT 陽性者が多く出る傾向がある。乙の知見はWest，

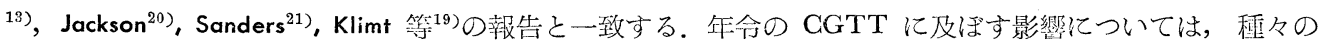
因子が考えられ ${ }^{29)}$ ，なかには而糖能と本質的には関係のないと思われる因子も含まれる。 Sanders ${ }^{21)}$ は40才 以上の者に対する CGTT の診断的価値は，40才以下の者に対するそれに比して低下することを主張してい る.

又年令層と無関係に, 出生序列と糖尿病前症発症との関連を見九私の成縝では, 出生序列の早い者程発生 率が高い，換言すれば糖尿病の発症には相当の期間を必要とすること意味する。しかし糖㽷病そのものの 発症が出生序列に関係があるといら報告は未だ㫕ない．乙の点からもCGTT の陽性と糖尿病発症との関連 について，なお検討を要する事項か残されている。

更に体型と CGTT との関連について，German ${ }^{15)}$ は40名の肥満者と，40名の非肥渾者を対象として，雨 者の間に有意の差がないとしている。糖㽷病が肥瀮者に多く発症するという事実と，上記の知見とが相反す るととから West $\left.{ }^{18}\right)$ は，CGTT が糖尿病前症者に必ずしも陽性に山るものではないという理由の一根挑に

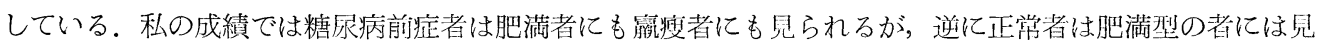
られなかつた。故に糖尿病前症者及びその疑いの者は肥满型において高率に見られるともいえるが，異常体 型者は少数であつたので，ての專項に関する結論を下すに到らない.

更に性と CGTT の関連に関して，Klimt 等 ${ }^{19}$ は一般に男性よりも女性の方が CGTT において高い血糖 值を示すととを報告し，女性そおいては，思性とは異なつた基準の下に䛦断すべき生理的性格があるかも知 れないと推定しているが，私の成績ではかかる傾向は見られず，CGTT 陽性者発生率はむしろ男性におい てやや高かつた。

2) 糖尿病においては糖代謝の暴常のみならず，脂質，蛋白代謝等多岐に亘る代謝異常がみられることが 近時漸く明らかとなつた。しかし現在までの知見では，やはり糖の代謝異常がその根幹であり，その他の代 謝異常は糖代謝異常による二次的現象として㴚明されるものが多い. 脂質, 蛋白質共に生体内においてエネ ルギー源となり得るととは周知の事実であるが，糖質の生体内エネルギ一生成における役割はその占める割 合という量的な面からも，必須であるという質的な面からも，脂質，蛋白質に比して独自の位置にある ${ }^{309}$.

かかる糖代謝に異常をみる糖尿病において，エネルギー生成の低下の芫られる事は容易に推論出来る。乙 の方面に関する現在までの知見は槇だ多い.

糖尿病患者の高エネルギー燐酸の生成は，多くは血液 $47 \mathrm{P}$ が指標となつている， その空腹洔血液 $\Delta 7 \mathrm{P}$ については正常者と変りがないとする者が多い. Meier and Thoenes ${ }^{31)}$ は重症糖疗病患者でも血液 $47 \mathrm{P}$ は 正常と変りがないとし，㛊藤 ${ }^{22}$ も健康体，糖尿病体共に平均 $4.3 \mathrm{mg} / \mathrm{dl}$ と雨者に差異を兌ていない.しかし 
万代 ${ }^{33}$ は健常者平均 $4.4 \mathrm{mg} / \mathrm{dll}$ 亿対して糖尿病者では平均 $2.7 \mathrm{mg} / \mathrm{dl}$ と有意の差をもつて低值を示すと報告し ている.

糖尿病前症における血液 $47 \mathrm{P}$ に関する報告には未で接しない．私の成績では，空腹時及びコーチゾン $50 \mathrm{mg} 2$ 回投与空腹時の血液 $47 \mathrm{P}$ は，糖尿病前症者においてやや低值を示す傾向は見られるが著明な差は認 められない.

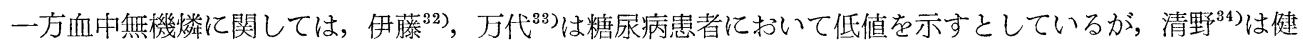
常者との間に有意の差を認めていない，糖㽷病前症と正常者を比較した私の成續でも，前者においてやや低 値を示す傾向はあるが顕著な差は認めなかつた。

以上の如く，空腹時血中無機燐及び $47 \mathrm{P}$ 值のみでは糖尿病又は糖尿病前症者と正常者の間に明確なる差 を見出すととは困難であるので，乙れらの值に変化を起す物質乃至は薬物を負荷して，その前後の值の変動 を比較することが，潜在的な異常を見る上からも有意義なととであると思われる。かかる見地から私は CGTT の前後及びインシュリン投与前後の血中無機燐及び $47 \mathrm{P}$ 值の変動を比較し, 糖尿病前症者におい ては正常者に比して，その変動の少ないてとを認めた。

ブドウ糖負荷が血中無機燐の減少をきたす理由としては，解糖のための燐の利用 ${ }^{35}$ ，高エネルギー燐酸化 合物の形成の関与 $\left.{ }^{33}\right)$ 等があげられている，同じ理由により血中 $47 \mathrm{P}$ は増加する. 糖尿病に際しては，この 減少の低下が見られる ${ }^{33) 35}$ のは当然である.

コーチゾンの血中無機燐に対する影響に関しては，伊藤 ${ }^{32)}$ は健康体におけるコーチゾン投与による血中無 機燐の減少を報告しており，更に糖尿病患者においてはその減少が健常者に比して少ないとしている. 又血 中 $47 \mathrm{P}$ はコーチゾン投与により減少し，更にての減少は糖尿病者では健常者に比して明らかに高度である と報告している。

以上，ブドウ糖並びにコーチゾンの健常者並びに糖尿病者の高エネルギー燐酸代謝に及ぼす影響を合わせ 考えると，コーチゾン・ブドウ糖の同時負荷は，雨者を個々に投与した場合より，血中無機燐及び $\Delta 7 \mathrm{P}$ 值の 変動に及ぼす影響はより一層大であると考えられる。従つて糖尿病前症における如く, その潜在性高エネル ギー燐酸代謝障害が軽度であると考えられる場合, 上述の如くコーチ・゙ン・ブドウ糖同時貸荷による検索は 有意義なものと思われる・

インシュリンの作用機序に関しては現在まで数多くの研究報告がなされており，それらの成績の全てを総 括し得る定説は未だ見られない，しかし，インシュリンが酸化的燐酸化を高め，従つて ATP の合成を增

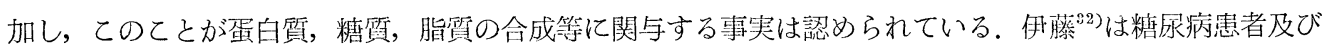
健常者にインシュリンを投与し，血中然機燐の減少並びに ATP の増加が糖尿病患者では正常者よりいず れも少ない事を報告している. 又万代 ${ }^{939}$ は糖尿病患者における血中無機燐の高值， $\Delta 7 \mathrm{P}$ の低值がインシュり ン治療により是正される事を報告している，本報の成績は，糖尿病前症者も又上述の糖尿病患者と同様の傾 向を有することを示した。

$\mathrm{B}_{1}$ は生体内でピロ燐酸エステルとなり活性化され ${ }^{36)}$ Carboxylase の補酵素となる. 附燐の際の燐酸供与 体としては，最近 Inosinetriphosphate, Guanosinetriphosphate も関与する事が報告されているが37), 主 なる供与体が ATP である事383940141342 は種々の事実より間違いない．いずれにしても，高エネルギー燐 酸供与体が必要である。

前述の如く，糖尿病においては高エネルギ一燐酸代謝の障害が諗められるので，それに伴つて $\mathrm{B}_{1}$ 活性化の 障害が見られるであろう事は容易に推定出来る。乙の点に関する研究はインシュりンとの関連において，現 在までに数多くの報告がなされている．Foa 等 $\left.{ }^{43}\right)$ は正常犬に注射された $\mathrm{B}_{1}$ は直ちに燐酸化されるが，膵摘 犬ではての燐酸化が障害されているてとを羿め，ての障害はインシュリンを投与するととにより取除かれる

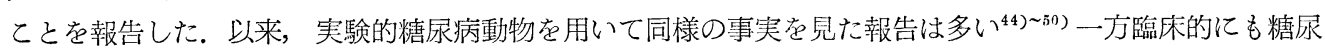
病に見られる $\mathrm{B}_{1}$ 利用障害がインシュリンにより改善されるととが認められている51522).

私の実験においても，糖尿病患者の血中結合 $\mathrm{B}_{1}$ 量は正常者のそれに比して著明に低く， $\mathrm{B}_{1}$ 附燐能は高 第38巻 第10号 
度に障害されている。乙れらの事実は $\mathrm{B}_{1}$ を負荷するととにより一層著明となる。同時に $\mathrm{B}_{1}$ 負荷後尿中 $\mathrm{B}_{1}$ 排泄量は糖家病患者では正常者より遙かに多く， $\mathrm{B}_{1}$ の利用障害のある事を示しており，軽度ではあるが これと全く同様の傾向が糖尿病前症者においても認められた。

$\mathrm{B}_{6}$ も又生体内で燐酸エステルとなり活性化され, 主として Pyridoxal phosphate として, Amino acid decarboxylase, Transaminase 等の Co-Enzyme となる事はよく知られている. 又との活性化の際にも ATP が必要である゙ッ。 それ故 Pyridoxine を投与して血中 Pyridoxal Phosphate の消長をみた本報告の 成績は，糖尿病前症にわける高エネルギ一燐酸代謝の一標示となりうる事は前述の $\mathrm{B}_{1}$ の場合と同様であ る。それに加えて， $\mathrm{B}_{6}$ は現今その久乏が動物に糖㽷病を起す唯一のビタミンであると考えられるので，糖 尿病前症におけるその動態は特に興味が持たれる。即ち古武は $\mathrm{B}_{6}$ 久乏状態における Tryptophan の異常 代謝産物である Xanthurenic acid が diabetogenic action を有し，Xanthurenic acid 糖尿白ネズミに見 られる高血糖, 尿糖, 膵ラ氏島のF細胞の萎縮を報告した ${ }^{54}$. 又当教室においてての際における血糖値と末梢 血インシュリン活性の逆相関を見だ . 更に実験的アロキサン糖尿を発症させるに必要なアロキサンの最少 至適量は， $\mathrm{B}_{6}$ 欠乏白ネズミにおいては健常白ネズミのそれに比し少ない去等, 糖尿病発症と $\mathrm{B}_{6}$ との関連 に関する知見は多い.

本報告においては糖尿病前症に見られる $\mathrm{B}_{6}$ 附燐能低下の傾向を，一応高エネルギ一燐酸代謝障畫の一標 示として取扱つたが，乙の事実が糖冢病発症又は進展に何らかの原因的意味を有しているか，或いは単洁結 果であるかは，なお検討を要する興味ある問題である。

3）血中インシュリン量は，採血の条件，検体とするまでの処理法，及び測定法の相異により種々の值が 出され，又出された值に刘する解稂も全く異なつたものとなり得る。

本報に用いた方法は，未梢静脈血よりインシュリンを抽出して検体となし，下垂体副婜剔出白ネズミ在用 いて測定する in vivo の方法ででる。

糖尿病前症者の血中インシュリン量に関しては，Steinke 等 ${ }^{56}$ の正常者よりも高値をとるという報告があ るが，私の成績では特別な傾向を認めず，值の分布範囲も正常者とほぼ同じで，分布において正常者のそれ よりやや低値をとるものが多かつた。，且つ岤瘦型の者は低值をとるという事実は糖尿病患者についての知見 7)と同じである.

又血中インシュリン量と，インシュリン感性に及ぼす PAL-P の影響に関する本報の知見は，当教室小 出 ${ }^{8)}$ が糖尿病患者について得た結果と全く同一の傾向を示す。。ての事実は, 糖尿病はその登症当初より既に インシュリン利用障害型とインシュリン欠型とを示すもののある事を推定せしめる。

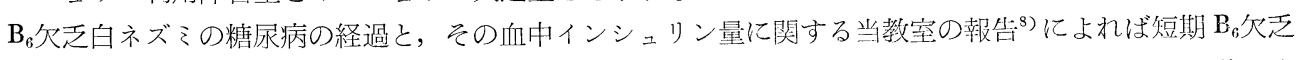
糖尿白ネズミの血中インシュリン量は正常值よりもむしろ高く, 長期 $\mathrm{B}_{6}$ 不足糖尿白ネズミのそれは著しく 低值を示し，それぞれインシュリン利用障害型，インシュリン欠泛型を示す。人の糖尿病においてもインシ ュリン利用障害又は過剩需要をもたらす様な何らかの生体の変化がインシュリン過剩分沧を促し，遂には膵 ラ氏島を疲弊に陥入らせるという病態の推移は, 上記 $\mathrm{B}_{6}$ 欠乏白ネズミの経過と考光合わせ容易に推定出来 るところであるが，一方人においてはての様な病態の推移とは別に，本報の知胃は発症当初から既に 2 型が それぞれ独立して発症する可能性を示唆する。

更に糖尿病患者とその家系者が，血中インシュリン量において同じ傾向を示す事は，もし家系者中の前症 者が糖尿病に発展した場合その家系に見られる患著と同じような病型を形成するとすれば，未だ種々検討を 要する点はあるが一応次の仮説を立てるてとが出来る, 即ち, 少なくとも可成り多くの糖尿病は発症当初よ り全経過を通じてインシュリン利用障害型とインシュリン火型の 2 群に分けられる. 更にいずれの型の糖 尿病になるかは，遺伝的に受け継がれた素因に基づいて決定される。

但し, 前述の如く本報の血中インシュリン量の測定は未梢静脈血を用いているので，同じくインシュリン 量が低值を示すとしても，それが膵のインシュリン産生の低下によるものか，末梢におけるインシュリンの 過剩消費によるものかはなお検討を要する，糖尿病患者とその家系中の前症者に見られる血中インショリン 
量が同じく低值を示す場合，その機序の差異の有無を究明することは，糖永病成因に関する上述の仮説の当 否を決める上に極めて重要な事である. 又 Owen 等57 は糖尿病前症者の血清アルブミン分画に抗インシュ リン因子のあるてとを指摘し, 糖尿病の発症の原因は抗インシュリン因子を過剩に形成する遗伝的要因と, てれに対する膵ラ氏島 $\beta$ 細胞のインシュリン産生能力の優劣によるとしている。本報に用いられて測定法は 抽出過程において一尤抗インシュリン因子は除かれていると考觉てよく, 又抗インシュリン因子そのものに 関する検索は行なつていないので，乙の点には触れない。

4）以上各項目について，糖尿病前症に見られる買常を主として阽尿病との比較において考察したが，全 体を通じて高える事は，本報に見られた知見に関する限りでは，糖尿病前症に見られる異常は糖沓病に見ら れるそれと著しく類似しており，その差異は量的なものであるという事である。乙の事実は糖尿病成因の究 明仁一つの示浚を与えるとともに，現今未だ倹封の余地を残している糖录病の診断法及びその基準に関する 考察に一つの資料在提供するものと考える.

\section{結 言}

1) 糖求病家系者中の非糖尿病者 41 名に CGTT を行ない20名 $(49 \%)$ の糖尿病前症者をみた。前症者発 症率は高合者, 出生序列の早い者に高く, 体型別では著朋な差はなく, 男性にやや高率に胃られた。

2) CGTT，及びインシュリン負荷前後の血中無機燐， $47 \mathrm{P}$ を測定してその变動を比較した結果，糖求病 前症者では正常者に比してその変動が少なかつた。 又 $\mathrm{B}_{1}, \mathrm{~B}_{6}$ 色負荇して, それに対する附燐能を比較し, 糖尿病前症者では正常者化比して附燐能が低下している事を認めた。

以上の結果上り糖尿病前症には既に高エネルギ一燐酸代謝に障害のあるととがうかがわれる。

3）糖尿病前症者では正常者に比してインシュリン感性の低下の傾向が見られた，又糖尿病前症者の血中 インシュリン量值は正常者，糖尿病者之同様広い分布を示すが，血中インシュリン量とインシュリン感性に 及ぼす PAL-P の影響との関連を見ると，糖尿病者に見られるそれと全く同じ傾向を示すてての事実は糖尿 病前症の時期において既にインシュリン利用障害型とインシュリン久乏型の 2 型が存在するととを示唆する. 又糖尿病家系中の非正常者の血中インシュリン量は, 同一家系中の糖尿病者のそれと同じ傾向を示す。従つ て上記 2 型のうちいずれの型の糖尿病になるかは遺伝的素因に左右される事が推定出来る.

終りに臨み御指導並びに御校閲を睗わりました恩师山田弘三孝教授に深甚なる感謝态捧げます。，又研究を共 にして顶いた糖尿病研究班の各位に愿く御礼申上げまず.

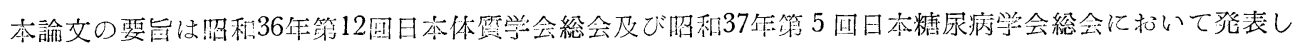
た.

\section{文献}

1) FAJANS, S.S. and J.W. CONN : Diabetes, $3: 296$, (1954).

2) CONN, J.W. : Am. J. Med. Sc., $199:$ 555, (1940).

3) WILKERSON, H.L.C. and Q. R. REMEIN : Diabetes, $6: 324$, (1957).

4) 藤井 : 生化学䒠驗法, 定量編 (昭33).

5) 市原：生化学，28:824，(1957)

6) JOSLIN, E.P., et al : The Treatment of Diabetes Mellitus, 10th Edition, (1959). 7) 柴田 : 日内誌, 36 : 93, (昭35)。 8 8) 小出 : 日内誌, $38: 4$, (昭37). $\quad 9$ ) CONN, J.W., et al : J. Lab. Clin. Med., $33: 651,(1948)$ 10) CONN, J.W.J. : Clin. Endocrinol., 10:825, $1950 . \quad 11$ ) FAJANS, S.S. and J.W. CONN : Clin. Res. Proc., $3: 122$, (1955). 12) PAPPER,S. et al. : J. Lab. Clin. Med., $48: 13$, (1956). 13) WEST, K.M. : Diabetes, $6: 168$, (1957). HOLTEN, C., et al : Acta Med. Scandinav., $157: 257$, (1957). 15) GERMAN, J.L. : Diabetes, $7: 261$, (1958). 16) WEST, K.M. : Diabetes, $8: 22$, (1959).

17) GOTO, Y., et al : Lancet, $2: 461$, (1960).

18) WEST, K.M. : Diabetes, $9: 379$, (1960). 19) KLIMT, 第38巻 第10号 
C.R., et al : Diabetes, $10: 351,1961$.

21) SANDERS, M.J. : Diabetes, $10: 41$, (1961).
20) JA.CKSON, W.P.U. : Diabetes, $10: 33$, (1961).

22) GOUDIE, R.B., et al : J. Clin. Path., $11: 428$, (1958). 23) LAMBERT, T.H. et al : Ann. Int. Med., 54 : 916, (1961). JACKSON, W.P.U. : Brit. M.J., 2 : 690, (1952).

25) JACKSON, W.P.U. and N. WOOLF : Lancet. $1: 614$, (1957).

26) JACKSON, W.P.U. and N. WOOLF : Diabetes, $7: 446$, (1958). 27) JACKSON, W.P.U. : Diabetes, $9: 373$, (1960). 28) CONN, J.W. : Diabetes, $7: 347$, (1958). 29) FAJANS, S.S. and J.W. CONN : Diabetes, $10: 1$, (1961). LEVINE : Carbohydrate Metabolism, 2nd Edition, (1952). 30) SOSKIN, S. and R. Arch. Exp. Path. Pharm., 161 : 119, (1931). 32) 伊藤 : 東北医誌，56:592，(明 32 ). 万代：日内分泌誌，34:472，(昭33). 34) 清野 : 東北医誌，54:205，(昭31).

35) THORN, G.W., et al: Diabetes Mellitus, in Principles of Internal Medicin edited by Harrison. (1954). 36) LOHMAN, K. and Ph. SCHUSTER : Biochem. Z., $294: 183$, (1937).

37) 島薗: ビタミ ン, $13: 71,(1957)$ 38) 堀田: ビタミン, $2: 88,(1949)$.

39) 桂: ビタミン, $7: 897$, (1954). 40) 井上：ビタミン, $7: 599,(1954)$.

41) 山村: 第78回ビタミンB研究協議会 報告 (1955)。 42) 島菌：ビタミン, 9:69, (1955). 43) FOR, P.P. et al : Arch. Biochem., $13: 449$, (1947). 44) SMITH, J.A., et al : Biochem. Biophys. Acta, $5: 535$, (1950). 45) SMITH, J.A. et al : Arch. Biochem., $40: 323$, (1952). 46) 町田 : ビタミン, $8: 320$, (1955). 47) 町田：ビタミン, $8: 324$, (1955). 48) FOA, P.P. et al : Arch. Biochem. $40: 323$, (1952). 49) SILIPRANDI, D., et al : Nature, $169: 329$, (1952).

50) 薗田: ビタミン, $14: 481,(1958)$. 51) 沢田：ビタミン, $10: 447$, (1956). 52) 山口 : ビタミ ン, $8: 479,(1955)$. 53）須田：酥素化学の進歩，符 1 集，(昭24）。 54) 古武 : 生化学, $28: 1, \quad$ (1956). 55) 神崎 : 名医誌, $81: 497$, (1960). 56) STEINKE, J. et al : Metabolism, $10: 707$, (1961). 57) Owen, J.V. et al : Lancet, $1: 806$, (1961). 